\title{
Gambaran Tingkat Pengetahuan Siswa SMA Negeri Kelas XII di Kota Bandung tentang Penyakit Diabetes Mellitus Tipe 2
}

\author{
Nyayu Mevia Fiqi*, Zulmansyah \\ Prodi Pendidikan Kedokteran, Fakultas Kedokteran, Universitas Islam \\ Bandung, Indonesia. \\ *meviafiqi08@Gmail.com, zulmansyah@unisba.ac.id
}

\begin{abstract}
According to American Diabetes Assosiation (ADA) Diabetes mellitus (DM) is a group of metabolic diseases characterized by hyperglycemia resulting from defects in insulin secretion, insulin action, or both. World Health Organization (WHO) predicted an increase of DM patient from 8.4 million to 21.3 million from 2000 to 2030. International Diabetes Federation (IDF) predicted an increasing trend of the disease from 9.1 million in 2014 to 14.1 million in Indonesia by 2035. This research is created to analyze the knowledge of the last year senior state high school students in Bandung about Diabetes Mellitus Type 2. The research methodology was carried out with a cross-sectional approach and the sampling technique was simple random sampling which was following the inclusion criteria using the Starr Country (2001) questionnaire. The results of the study were obtained from 397 students, who had the highest level of knowledge about diabetes mellitus was in the moderate category, which is 326 people ( $82 \%)$, based on the highest gender were women, the moderate category was 202 people $(82 \%)$, based on the family history, there is no family history of diabetes, about 289 people ( $84 \%$ ) with a moderate category. The conclusion is that the knowledge of senior high school students in Bandung about DM type 2 is a moderate category.
\end{abstract}

Keywords: Family History of DM, Gender, Knowledge about DM.

\begin{abstract}
Abstrak. Berdasarkan American Diabetes Assosiation (ADA) Diabetes Mellitus (DM) adalah sekelompok penyakit metabolik yang ditandai dengan hiperglikemia akibat kerusakan sekresi insulin, kerja insulin, atau keduanya. World Health Organization (WHO) memprediksi dari 8,4 juta penderita DM pada tahun 2000 menjadi sekitar 21,3 juta pada tahun 2030. International Diabetes Federation (IDF) memprediksi di Indonesia tahun 2014 sekitar 9,1 juta menjadi 14,1 juta di tahun 2035. Tujuan penelitian adalah mengukur tingkat pengetahuan siswa kelas XII SMA Negeri Kota Bandung terhadap penyakit Diabetes Mellitus Tipe 2. Metode penelitian dilakukan dengan pendekatan cross sectional dan teknik pengambilan sampel secara simple random sampling yang sesuai dengan kriteria inkulusi dengan alat bantu kuisioner Starr Country (2001). Hasil penelitian diperoleh dari 397 orang siswa, yang memiliki tingkat pengetahuan tentang penyakit DM terbanyak adalah kategori sedang, yaitu 326 orang $(82 \%)$, berdasarkan jenis kelamin terbanyak adalah perempuan, kategori sedang jumlah 202 orang $(82 \%)$, berdasarkan riwayat keluarga terbanyak adalah tidak ada riwayat keluarga menderita DM, kategori sedang jumlah 289 orang (84\%). Simpulan dari penelitian ini bahwa tingkat pengetahuan siswa SMA Negeri di Kota Bandung terhadap penyakit DM tipe 2 termasuk dalam kategori sedang.
\end{abstract}

Kata Kunci: Jenis Kelamin, Riwayat Keluarga, Tingkat Pengetahuan DM. 


\section{A. Pendahuluan}

Berdasarkan American Diabetes Assosiation (ADA) Diabetes Mellitus (DM) adalah sekelompok penyakit metabolik yang ditandai dengan hiperglikemia akibat kerusakan sekresi kerja insulin, atau keduanya. Diabetes mellitus menjadi ancaman kesehatan global, karena berdasarkan World Health Organization (WHO) dan International Diabetes Federation (IDF) diprediksi akan adanya peningkatan kasus yang tinggi. World Health Organization memprediksi dari 8,4 juta penderita DM pada tahun 2000 menjadi sekitar 21,3 juta pada tahun 2030, sedangkan IDF memprediksi akan terjadinya kenaikan jumlah penyandang DM di Indonesia dari tahun 2014 sekitar 9,1 juta menjadi 14,1 juta pada tahun 2035. DM melitus juga diketahui dapat mengakibatkan kompilkasi yang serius pada jantung, pembuluh darah, mata, ginjal dan syaraf. Pada tahun 2017, terjadi sebanyak 270.702 kematian disebabkan oleh DM.

DM tipe 2 adalah jenis DM yang sering terjadi di masyarakat, biasanya terjadi pada orang dewasa, akan tetapi kejadian DM tipe 2 pada anak-anak dan remaja semakin meningkat. Faktor risiko paling utama pada DM tipe 2 adalah obesitas dan riwayat keluarga dengan riwayat DM tipe 2. Hal ini menandakan bahwa edukasi mengenai penyakit diabetes perlu ditingkatkan untuk mendorong gaya hidup sehat sedini mungkin, sehingga dapat menekan angka kejadian DM di Indonesia dan menunjukkan lebih banyak yang harus dilakukan untuk mengatasi kesadaran faktor risiko terkait diabetes dan prediabetes.

Dari latar belakang diatas maka rumusan masalah yang diambil adalah sebagai berikut "Mengukur bagaimana tingkat pengetahuan DM tipe-2 pada siswa SMA Negeri di Kota Bandung berdasarkan jenis kelamin \& riwayat keluarga DM." Selanjutnya, tujuan dalam penelitian ini diuraikan dalam pokok-pokok sbb:

1. Mengukur tingkat pengetahuan DM tipe 2 pada siswa berdasarkan jenis kelamin.

2. Mengukur tingkat pengetahuan DM tipe 2 pada siswa berdasarkan riwayat keluarga dengan DM.

\section{B. Metodologi Penelitian}

Metode penelitian dilakukan dengan pendekatan cross sectional dan teknik pengambilan sampel secara simple random sampling yang sesuai dengan kriteria inkulusi dengan alat bantu kuisioner Starr Country (2001).

Semakin berkembangnya teknologi dan semakin banyak informasi yang disajikan oleh media massa, social media, buku dan yang lainnya ke masyarakat dapat mempengaruhi pengetahuan dari seorang individu, bahkan informasi yang kerap kali hanya diketahui oleh ahli dalam bidang tertentu, saat ini dapat diakses oleh masyarakat awam. Khususnya dalam bidang kedokteran sudah sangat banyak perangkat online yang memudahkan masyarakat untuk mendapatkan informasi baik melalui website kesehatan mapun aplikasi berbasis online yang memungkinkan seseorang untuk berkonsultasi dengan dokter melalui fitur chatting. Hal ini juga berpengaruh pada pengetahuan masyarakat terhadap DM.

Apabila masyarakat dapat mengakses info tentang DM maka tingkat pengetahuan terhadap penyakit DM juga akan meningkat dimana DM sendiri merupakan kondisi yang ditandai dengan peningkatan kadar glukosa darah (atau gula darah) yang memiliki gejala trias klasik meliputi poliuri, polidipsi, dan polifagi. Dikarenakan angka kejadian pada DM tiap tahunnya meningkat maka diperlukannya pengetahuan terhadap DM untuk mengurangi angka kejadian pada masa yang akan datang, khususnya pada siswa kelas XII SMA dikarenakan pada siswa kelas XII dibutuhkan bekal terhadap pengetahuan tentang DM karna akan mereka akan bekerja atau melanjutkan studi yang jauh dari pantauan orang tua.

Perhitungan tingkat pengetahuan DM pada siswa kelas XII SMA ini akan diukur menggunakan kuisioner Starr Country yang nantinya akan diinterpretasikan dalam kategori baik apabila jawaban benar 18-24, sedang 9-18, buruk 0-9. 


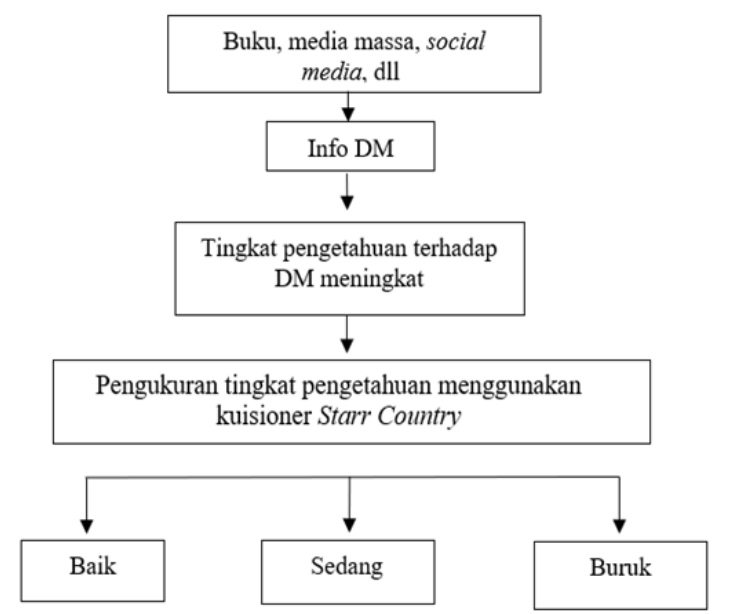

\section{Hasil Penelitian dan Pembahasan}

Diperoleh sebanyak 397 orang siswa kelas XII SMAN Kota Bandung dengan sebesar $62 \%$ subjek berjenis kelamin wanita dan hanya $13 \%$ dengan riwayat keluarga dengan dm dengan tingkat pengetahuan dengan kategori sedang $82 \%$ hal ini dapat dilihat pada tabel 1 .

Tabel 1. Karakteristik subjek

\begin{tabular}{llcc}
\hline Variabel & & (n) & Persentase \\
\hline Jenis Kelamin & Pria & 151 & $38 \%$ \\
& Perempuan & 246 & $62 \%$ \\
\hline Riwayat Keluarga & Ada & 53 & $13 \%$ \\
& Tidak Ada & 344 & $87 \%$ \\
\hline \multirow{2}{*}{ Tingkat Pengetahuan } & Baik & 18 & $5 \%$ \\
& Sedang & 326 & $82 \%$ \\
& Buruk & 53 & $13 \%$ \\
\hline Jumlah & & & $100 \%$ \\
\hline
\end{tabular}

Tingkat pengetahuan DM, diperoleh hasil dengan kategori baik, sedang dan buruk yang dihubungkan dengan jenis kelamin dapat dilihat pada tabel 2.

Tabel 2. Distribusi Tingkat Pengatahuan Responden

\begin{tabular}{ccccc}
\hline Variabel & & Kategori & (n) & $\mathbf{\%}$ \\
\hline \multirow{3}{*}{ Jenis } & \multirow{2}{*}{ Perempuan } & Baik & 14 & $6 \%$ \\
Kelamin & Sedang & 202 & $82 \%$ \\
\cline { 2 - 5 } & & Buruk & 30 & $12 \%$ \\
\cline { 2 - 5 } & \multirow{2}{*}{ Laki-Laki } & Baik & 4 & $3 \%$ \\
& & Sedang & 126 & $83 \%$ \\
\cline { 2 - 5 } & Bumlah & & 397 & $14 \%$ \\
\hline
\end{tabular}

\section{Berdasarkan Jenis Kelamin}

Berdasakan tabel 2 didapatkan hasil dari subjek berjumlah 246 orang perempuan bahwa tingkat pengetahuan berdasarkan jenis kelamin perempuan sebagian besar berada pada kategori sedang 202 orang (82\%), sedangkan tingkat pengetahuan berdasarkan jenis kelamin laki-laki dari subjek berjumlah 151 orang didapatkan sebagian besar berada pada kategori sedang 126 orang $(83 \%)$. 
Tabel 3. Distribusi Tingkat Pengetahuan Responden

\begin{tabular}{ccccc}
\hline Variabel & & Kategori & (n) & \% \\
\hline & & Baik & 10 & $19 \%$ \\
Riwayat & Ada & Sedang & 39 & $74 \%$ \\
Keluarga & & Buruk & 4 & $8 \%$ \\
\cline { 2 - 4 } DM & Tidak & Baik & 8 & $2 \%$ \\
& ada & Sedang & 289 & $84 \%$ \\
\cline { 2 - 4 } & Buruk & 47 & $14 \%$ \\
\hline & Jumlah & & 397 & $100 \%$ \\
\hline
\end{tabular}

\section{Berdasarkan Riwayat Keluarga DM}

Hasil yang didapatkan oleh tabel 3 tingkat pengetahuan berdasarkan riwayat keluarga DM dengan jumlah subjek 53 orang, sebanyak 39 orang (74\%) dengan adanya riwayat keluarga DM dalam kategori sedang. Tingkat pengetahuan berdasarkan tidak adanya riwayat keluarga DM dengan jumlah 344 orang, didapatkan hasil sebanyak 289 orang (84\%) dengan kategori sedang.

\section{Kesimpulan}

Berdasarkan pembahasan dalam penelitian ini, peneliti menyimpulkan beberapa hasil penelitian sebagai berikut:

Perbedaan jenis kelamin terhadap masalah kesehatan akan mempengaruhi seseorang untuk memiliki gaya hidup yang sehat. Jenis kelamin merupakan salah satu faktor predisposing seseorang untuk berperilaku menurut Lawrence Green dalam Soekidjo Notoadmodjo (2010). Cara pandang dapat dipengaruhi oleh jenis kelamin dan hal itu dapat menyebabkan perbedaan presepsi yang dapat mempengaruhi sikap dan perilaku diantara keduanya.

Perbedaan tingkat kesadaran terhadap diabetes mellitus dapat disebabkan karena anggota keluarga memiliki riwayat diabetes mellitus yang menyebabkan anggota keluarga yang lainnya memiliki kesadaran yang lebih baik tentang kejadian penyakit. Seseorang yang memiliki riwayat keluarga diabetes lebih sering untuk mengkonsumsi buah \& sayur secara teratur serta ikut berpartisipasi dalam skrining gula darah. Berdasarkan tabel 3 menunjukan bahwa adanya riwayat keluarga dapat mempengaruhi tingkat pengetahuan seseorang terhadap penyakit tersebut, sebagian besar kategori baik dimiliki oleh seseorang dengan riwayat keluarga sebanyak 10 orang (19\%) sehingga riwayat keluarga dapat dikaitkan dengan kesadaran yang lebih baik tentang faktor risiko pada diabetes mellitus.

Hasil uji Chi Square dengan penggunaan fasilitas Crosstab pada program Statistical Product and Service Solutions ( SPSS) menunjukan angka signifikan ( $p$-value 0,22). Hasil uji Chi Square dikatakan signifikan apabila $P$-value $<0,05$. Variabel diambil dari jumlah kuisioner yang memiliki jawaban salah paling banyak yaitu pertanyaan nomor 17 pada kuisioner yang hanya dijawab benar oleh 35 dari keseluruhan 397 responden. Tujuan dilakukannya uji Chi Square ini adalah membuktikan bahwa pertanyaan dengan jumlah terjawab benar paling sedikit memiliki pengaruh terhadap total skor responden dengan ratarata sedang. Penelitian lainnya yang dilakukan oleh Al Hussaini (2015) menunjukan bahwa tingkat pengetahuan tentang diabetes mellitus pada remaja usia 16-20 tahun dengan 4062 responden di Kuwait mendapatkan hasil $63,2 \%$, hasil penelitian ini menunjukan bahwa para remaja memiliki pengetahuan umum tentang penyakit tersebut dengan cukup baik. Meskipun tingkat pengetahuan pada remaja baik, alangkah baiknya untuk menekankan pemberian pengetahuan remaja terkait diabetes mellitus karena pada usia ini sangatlah penting untuk deteksi dini dari penyakit tersebut. Pernyataan ini sesuai dengan penelitian ini dikarenakan pada penelitian ini didapatkan sebanyak 326 orang (82\%) memiliki pengetahuan sedang yang menandakan bahwa para siswa telah cukup memahami penyakit diabetes mellitus yang dapat meningkatan rasa kewaspadaan dan dapat mengontrol faktor risiko terhadap penyakit ini di 
kemudian hari.

\section{Daftar Pustaka}

[1] Al-Hussaini M, Mustafa S. Adolescents' knowledge and Awareness Of Diabetes Mellitus In Kuwait. Alex Jour of Med. 2015 April 15;52(1):61-66

[2] Andrade C. The P Value and Statistical significance:Misunderstandings,Explanations, Challenges, and Alternatives. Ind Jour of Psyc Med. 2019 April 13;41(3):210-215

[3] American Diabetes Association. Diagnosis and classsification of Diabetes Mellitus. Diab Care.2010 Jan;33:62-69

[4]American Diabetes Assosiation [Homepage on the internet]. America:Statistics About Diabetes [updated 2018 March 22] Tersedia dari:https://www.diabetes.org/resources/statistics/statisticsaboutdiabetes\#: :text=Diabetes $\% 20$ may $\% 20$ be $\% 20$ underreported $\% 20$ as, the $\% 20$ underlying\%20cause $\% 20$ of\%20death

[5] Kurniawan AA, Wuryaningsih YNS. Physical Exercise Recommendations for Type 2 Diabetes (Rekomendasi Latihan Fisik Untuk Diabetes Melitua Tipe 2).Berk Ilm Kedokt Duta Wacana. 2016 Sept:197-208

[6] Manaf P, Novida H, Rudjianto SA, Suastika K, Sanusi H, Yuwono A dkk. Konsensus Perkumpulan Endokrinologi Indonesia Pengelolaan dan Pencegahan Diabetes Melitus Tipe 2 Di Indonesia. Jakarta; PB. Perkeni; 2015

[7] Notoatmodjo Soekidjo. Metodologi Penelitian Kesehatan. Jakarta: Rineka Cipta; 2014

[8]Piccinino L, Griffey S, Gallivan J, Lotenberg LD, Tuncer D. Recent Trends in Diabetes Knowledge, Perceptions, and Behaviors: Implications for National Diabetes Education. Heal Educ Behav. 2015 Augst;42(5):687-96

[9] Siti J, Serli AR. Tingkat Pengetahuan Remaja Tentang HIV/AIDS Pada Siswa Kelas XI di SMA Negeri 1 Bulu Sukoharjo. Jur Ilm Kes. 2016 Sept;8(2):54-57

[10] Wathoni N, Aliya NH, Sriwidodo, Elasari DP, Hana L, dkk. Persepsi, Kesadaran, dan Pengetahuan Diabetes Melitus Di Salah Satu SMA Di Pangandaran. J Apl Ipteks untuk Masy. 2017 Maret;6(1):40-42

[11] World Health Organization [Homepage on the Internet] Diabetes[updated 2020 Juni 8] .Tersedia dari:https://www.who.int/news-room/factsheets/detail/diabetes. 